\title{
Globalisasi: IMF, Bank Dunia dan Amandemen Pasal 33
}

\author{
Hudiyanto
}

The following article investigates the globalization as an actual topic that rises in recent ten years. Talking about the globalization in Indonesia intends to conduct amendment of article 33 of The Constitution 1945. The majority of the member of Indonesian representatives state that refers to globalization, the article regarding economy must be abrogated. The author of this article tries to describe the substance between IMF and World Bank in actualizing the spirit of globalization by carrying out amendment of the constitution that closed relating to Indonesia micro-economy development. There is a crucial problem when the amendment article 33 of the Indonesian Constitution will be applied.

Olobis lobalisasi merupakan kata yang "harus" disebut kalau berbicara mengenai masalah ekonomi. Secara lebih khusus globalisasi selalu dipadankan dengan liberalisasi dalam perdagangan dunia khususnya setelah Sidang GATT Putaran Uruguay (Uruguay Round) di Marrakesh, Maroko, tahun 1993. Oleh karenanya globalisisasi merupakan topik menarik bagi banyak pihak terutama dalam sepuluh tahun terakhir. Selalu dianggap bahwa tanpa berbicara tentang globalisasi, sebuah topik pembicaraan belum sempurna atau kurang afdhal. Di Indonesiapun pembicaraan tentang globalisasi bahkan sempat membuat bimbang sebagian orang ketika harus melakukan amandemen atas pasal 33 UUD 1945. Di satu pihak sebagian anggota Tim Ahli BP MPR menyatakan bahwa seiring dengan semangat globalisasi, pasal tentang pengaturan ekonomi harus dihapuskan. Tulisan ini mencoba melihat benang merah antara semangat IMF dan Bank Dunia dalam mewujudkan semangat globalsiasi dengan amandemen konstitusi kaitannya dengan masa depan pengembangan ekonomi mikro di Indonesia.

\section{IMF, Bank Dunia dan Globalisasi}

Ketika utang luar negeri di negaranegara sedang berkembang menggunung, pertanyaan yang muncul tentu adalah mengapa harus berutang? Mencari utang luar negeri (dan mengundang investasi asing) dianggap merupakan suatu keharusan bagi negara sedang berkembang (NSB) karena mereka menghadapi apa yang disebut dua problema kesenjangan (Todaro, 1990). Masalah pertama adalah adanya kesenjangan antara ketersediaan dan kebutuhan dana untuk investasi (saving gap). Karena miskin, NSB memerlukan amat besar dana untuk membangun prasarana dan industri di semiua sektor, namun di saat yang sama tabungan masyarakat tidak mampu memenuhinya, sehingga jalan utang luar negeri harus ditempuh. Alasan kedua adalah bahwa serbakekurangan di NSB menyebabkan 
kebutuhan devisa untuk mengimpor barang modal (mesin-mesin, teknologi) berikut bahan baku untuk mengembangkan industri dan kebutuhan pokok amat besar. Namun di sisi lain aktivitas ekspor yang menghasilkan devisa amat terbatas. Defisit valuta asing inilah yang memberi dorongan kuat NSB untuk berutang.

Dua alasan itu kemudian mendorong NSB berlomba berutang ke luar negeri, sampai-sampai sejumlah negara menjadi negara dengan utang menumpuk (highly indebted countries). . Termasuk dalam kelompok ini adalah Brasil, Mexico, Uruguay, Argentina, Chill, Tunisia, Philipina, dan Indonesia. Sejumlah negara mengalami kebangkrutan ekonomi (dan pemerintahan) seperti yang dialami oleh Mexico (1985), Indonesia (1997), dan Argentina (2002). Negeri terakhir bahkan harus mengalami pergantian Presiden sebanyak 5 kali hanya dalam tempo 2 minggu. Kesemuanya ambruk ketika utang luar negeri mencapai angka di atas $\$ 100$ milyar.

Krisis ekonomi karena utang yang menumpuk (debt crisis) akhirnya memunculkan fenomena yang dihadapi NSB berupa Paradoks Utang Luar Negeri. Utang mereka dari tahun ke tahun semakin membesar tetapi tidak disertai dengan kemampuan untuk membayar kembali (repayment capacity). Paradoks ini mengatakan bahwa semakin besar NSB membayar kembali cicilan dan bunga utang, justru semakin besar utang baru diperlukan (the more debtors pay, the more they owe). Atau dengan kata lain negara pengutang terjebak dalam kondisi gali lubang tutup lubang. Ilustrasi untuk Indonesia bisa dilihat pada cicilan utang pertahiun Indonesia yang selalu lebih besar dari utang baru yang setiap tahun harus dibuat. Tahun ini utang baru sebesar Rp 50 trilyun tetapi pada saat yang sama Indonesia harus membayar (cicilan dan bunga saja!) sebesar Rp 80 trilyun. Hal semacam ini paling tidak telah terjadi sejak tahun 1992, yang kesenjangannya makin lama makin melebar.

Fakta ambruknya negara pengutang besar menimbulkan pertanyaan, mengapa utang yang seharusnya sebagai cara melepaskan diri dari "problem dua jurang" ternyata berakibat buruk? Paradoks utang luar negeri muncul ketika peningkatan utang NSB ternyata tidak diikuti kemampuan membayar kembali (repayment capacity). Ketidakmampuan ini terjadi karena utang luar negeri telah mengalami distorsi baik dilihat dari proses maupun angkanya. Dilihat dari sisi proses seringkali dikatakan utang luar negeri dilakukan bukan atas dasar pertimbangan ekonomi melainkan atas pertimbangan non ekonomi dari para elit kekuasaan. Dari sisi angka, utang luar negeri telah mengalami kebocoran sebagai konsekuensi dari kondisi negara sedang berkembang yang secara kelembagaan lembek (soft country). Dalam kondisi semacam ini apa yang bisa diharapkan dari proyek yang dibiayai utang? Hanya inefisiensi dan daya saing rendah yang menonjol.

Melaksanakan sebuah kebijakan (positif) dengan mendasarkan diri pada asumsi-asumsi. yang sifatnya normatif merupakan cara pandang neo klasik yang digunakan oleh lembaga-lembaga donor. Dua lembaga donor yaitu IMF dan World Bank merupakan dua lembaga yang berbeda namun memiliki ideologi yang sama. Lembaga tersebut merupakan dua pilar sistem ekonomi pasca perang dunia ke-l!. World Bank dimaksudkan untuk menurunkan tingkat kemiskinan dan memperbaiki taraf hidup penduduk dengan berbagai bentuk pemberian utang di NSB, 
sedangkan IMF dimaksudkan untuk mengatasi persoalan keuangan. Tugas keduanya berbeda, namun memiliki semangat yang sama yaitu terciptanya tata dunia yang liberal, tercermin pada perdagangan dunia yang bebas (free trade), investasi antar negara yang tak dibatasi, dan dilakukannya privatisasi atas sektor publik.

Semangat dasar seperti itu dilandasi oleh keyakinan berlakunya asumsi yang umumnya digunakan oleh ekonom neo klasik, bahwa hanya faktor ekonomi yang berpengaruh terhadap perilaku ekonomi. Padahal dalam kenyataannya tidaklah demikian. Negara sedang berkembang yang terkenal dengan kelembagaannya yang lembek telah menjadikan persoalan utang menjadi pelik. Kondisi yang nampaknya digunakan untuk melepas surplus keuangan di negara-negara maju secara terhormat.

\section{Globalisasi:'Deskripsi Atau Preskripsi?}

Masalah gloabalisasi sebenarnya telah berlangsung pada abad-abad yang lalu ketika terjadi proses migrasi dan kolonisasi tanah tanah kosong pada masa lalu. Tetapi globalisasi yang menjadi fenomena sekarang ini merupakan satu proses yang berjalan secara lebih sistematis. Dalam bukunya Globalization Unmasked, Imperialism in the 21 th Century memberikan gambaran globalisasi sebagai berikut'.

Globalization is both a description and a prescription, and such it serves as both an explanation - or poor one, it has to be said-, and an ideology that currently dominates thinking, policy making and political practice. As a description, globalization refers to the widening and deepening of the international flows of trade, capital and technology within a single global marke.....as a prescription globalisation involves the liberalization of national and global markets in belief that free flows of trade, capital, and information will produce the best outcome for growth and human welfare.

Globalisasi bisa diletakkan sekedar sebagai sebuah deskripsi tentang apa yang sekarang sedang berlangsung di dunia, tetapi bisa pula dipandang sebagai sebuah preskripsi atau obat manjur. Sebagai sebuah deskripsi globalisasi merupakan sebuah penggambaran (description) dari kecenderungan dunia saat ini. Namun globalisasi juga bisa juga dipandang sebagai sebuah resep atau obat (prescription) dari segala permasalahan. Sebagai sebuah deskripsi, globalisasi merujuk kepada adanya perluasan darialiran perdagangan, teknologi, kapital dan informasi menuju sebuah pasar global yang terintegrasi (integrated global market). Dalam globalisasi pada akhirnya akan tercipta sebuah "kampung dunia" (global village) yang menunjukkan adanya perubahan perubahan yang amat kompleks sebagai konsekuensi dari dinamika perkembangan kapitalis seperti adanya persebaran (diffusion) nilai nilai dan budaya yang menyertai proses pembangunan.

Namun lebih dari itu, banyak pihak yang meyakini globalisasi bukan sebagai deskripsi melainkan sebagai sebuah keyakinan, ideologi, atau obat paling manjur dari persoalan umat manusia. Sebagai sebuah resep atau preskripsi globalisasi melibatkan suatu keyakinan bahwa perdagangan dan pergerakan kapital dan informasi yang bebas akan menghasilkan hal terbaik bagi kesejahteraan umat manusia

1. James Petras dan Henry Veltmeyer, 2001, Globalization Unmasked, Imperialism in the 21 th Century 
baik dilihat dari kacamata global maupun nasional. Oleh karena itu dari sisi ini globalisasi dipandang sebagai cara terbaik dalam meningkatkan kesejahteraan umat manusia di muka bumi ini. Itulah yang banyak diyakini orang dan secara sistematis dilakukan oleh IMF dan Bank Dunia pasca Perang Duinia II lewat Bretton Woods.

Ketika globalsasi dilihat sebagai sebuah keyakinan atau ideologi inilah maka muncul kontroversi di dunia ketiga. $\mathrm{Hal}$ ini karena globalisasi diyakini sebagai suatu proses yang tak terelakkan (inevitable) sehingga hanya penyesuaian terhadap proses globalisasilah yang harus dilakukan. Karena globalisasi dianggap sudah tak mungkin dihindari maka semua kebijakan dengan penuh kesadaran diarahkan ke globalisasi. Dari kacamata mereka masalahnya tinggal bagaimana suatu negara atau kelompok negara bisa melakukan penyesuaian untuk bisa masuk dalam proses globalisasi yang menguntungkan. ${ }^{2}$ Dalam konteks inilah maka sejumlah ekonom di Indonesia yang mempunyai keyakinan globalisasi sebagaj resep akhirnya berupaya untuk menyesuaikan diri dengan arus dan keyakinan globalisasi. Hal ini tercermin dalam keinginan untuk menyesuaikan pasal 33 UUD 1945 dengan semangat globalisasi seperti dilakukan oleh sebagian Tim Ahli BP MPR yang membidangi masalah ekonomi (pasal 33) yaitu Sri Adiningsih, Syahrir, Sri Mulyani.

Tetapi Petras dan Veltmeyer meyakinkan bahwa pada sisi yang lainnya sejumlah pendapat menunjukkan globalisasi lebih merupakan "kerjaan sekelompok orang" (classs project) dari pada suatu proses yang tak terelakkan. Mereka lebih cenderung melihat perubahan dengan cara yang berbeda. Globalisasi dipandang sebagai. suatu alat ideologis untuk mengobati oleh suatu kelompok dan bukan hanya sebagai suatu deskripsi yang tepat. Dalam kaitan ini maka globalisasi sebenarnya bukanlah sesuatu yang tak terelakkan (inevitabe) melainkan sesuatu yang (justru) juga harus diantisipasi penanggulangannya.

Globalization is neither inevitable not necessary. Like the projects of capitalist development that preceded it (modernization, industrialization, colonialialism and development) the new imperialism is fraught with contradictions that generate forces of opposition and resistance and tha can undermine the capital accumulation process as well as the system on which it depends. The recent crisis of the Asian Economies (Indonesia, South Korea, Thailand, Malaysia, etc.) was deeply rooted in theirintegration into the world's financial markets and highly volatile movement of international capital (Petras dan Veltmeyer)

Globalisasi bukan tidak bisa dihindarkan (bisa dihindari!) tetapi sebenarnya juga tidak perlu untuk diikuti. Dalam kaitan Indonesia, kelompok ini diwakili antara lain oleh Mubyarto, Dawam Raharjo yang akhirnya keluar dari Tim Ahli BP MPR, dan di luar itu Sri Edi Swasono dan Revrisond Baswir.

Mengapa harus dihindari? Dengan menggunakan contoh Amerika Latin menggambarkan bagaimana imperialisme muncul di Amerika Latin oleh Eropa dan Amerika pada awal millennium baru. Buah dari globalsiasi adalah imperialisme ${ }^{2}$. Salah satu hal penting yang merupakan rekomendasi Bank Dunia dan IMF adalah

2 James Petras dan Henry Veltmeyer, 2001, Globalization Unmasked, Imperialism in the 21 th Century 
dilakukannya privatisasi di negara negara sedang berkembang. Pada tahun tahun 1950-an sampai 1970-an kapital dunia harus menghadapi proteksi ekonomi dalam negeri yang umumnya diterapkan $\mathrm{di}$ berbagai negara. Hal ini diwarnai dengan proses nasionalisasi berbagai perusahaan asing di negara-negara sedang berkembang, atau paling tidak kebijakan regulasi atas perusahaan perusahaan transnasional (transnational corporations), hambatan masuknya perusahaan perusahaan penanam modal asing (PMA, froreign direct investment) dan adanya intervensi negara dalam perekonomian. Iklim restriksi dan proteksi ini yang kemudian cepat berubah ke arah perekonomian yang serba bebas dalam dua dekade terakhir sehingga pasar dunia akhirnya mernjadi motor penggerak (engine of growth)

Ketika krisis ekonomi mulai melanda sejumlah negara, Choudowsky menulis sebuah buku yang secara diametral menantang pendapat bahwa IMF dan Bank Dunia dengan judul Globalization of Poverty: Impact of IMF and World Bank Reforms. Dari judul yang dibuat jelas bagaimana pandangan Choodowsky tentang peranan IMF dan Bank Dunia dalam memberikan pinjaman kepada negara-ṇegara sedang berkembang.

\section{Integrasi Ekonomi dan Collective Bargaining}

Ada' semacam kegamangan pada sejumlah pihak dalam menghadapi kecenderungan liberalisasi dan integrasi ekonomi di berbagai kawasan. Integrasi ekonomi telah memecah pendapat tentang relevansi dari koperasi di kemudian hari. Sejumlah pihak menyatakan bahwa koperasi tidak lagi relevan dan oleh karenanya - seharusnya pasal 33 UUD 1945 harus dirombak total. Wacana perombakan pasal 33 ini secara-efektif diikuti dengan dihapusnya mata kuliah koperasi dari kurikulum di berbagai perguruan tinggi. Pertanyaan yang sering muncul adalah apakah koperasi masih relevan dengan masa depan yang penuh dengan tuntutan efisiensi terutama berkaitan dengan isu dan tuntutan globalisasi dan liberalisasi dalam perdagangan dunia.

Berbeda dengan isu globalisasi, istilah dan isu liberalisasi rasanya lebih serius. Globalisasi pada awalnya muncul karena kemajuan teknologi yang memungkinkan informasi dan oleh karenanya budaya serta tata nilai akan bergerak ke segenap penjuru dunia tanpa mengenal batas-batas negara. Sebagai antisipasi maka setiap negara mempunyai kiat untuk tidak terseret dalam arus globalisasi baik dengan memperkuat teknologi komunikasi maupun dengan penguatan tata nilai yang dianut. Namun istilah liberalisasi yang muncul terutama setelah selesainya kesepakatan GATT putaran. Uruguay dengan konsep liberalisasi perdagangannya mempunyai dimensi yang lain yang lebih serius, lebih pasti dan lebih merepotkan. Liberalisasi ini mengandung unsur kemauan masing-masing negara untuk mau dipaksa untuk melakukan sesuatu yang mungkin bertentangan dengan kepentingan nasionalnya masing-masing. Paksaan itu terjadi karena kesepakatan itu berupa kesepakatan hitam di atas putih berikut sangsi-sangsi yang bisa dikenakan.

Kesepakatan perjanjian GATT putaran -Uruguay yang ditandatangani di Marrakesh pada' dasarnya ingin membersihkan perdagangan dunia dari hambatan non tarif dan' tarif yang berlebihan. Dengan menberikan kebebasan barang untuk keluar masuk suatu negara akan menyebabkan hanya industri yang efisien yang akan bisa 
bertahan dan "dihormati" konsumen. Untuk menjamin agar kebebasan bersaing itu benar-benar dilaksanakan maka berbagi aktifitas yang dianggap berkaitan (related) akan disorot secara tajam. Kegiatan itu adalah berkaitan dengan Hak Milik Intelektual yang berkaitan dengan perdagangan (Trade Related Intellectual Property Rights) (TRIPs) dan pengaturan investasi yang berkaitan dengan perdagangan (Trade Related Investment Measures/TRIMs). Berkaitan dengan TRIPs, maka hak milik intelektual diikuti secara universal dan harus dihormati oleh negara anggota WTO. Setiap pengomersilan setiap produk harus seijin dan membayar royalty kepada pemilik hak cipta dan patennya. Berkaitan dengan TRIMs maka diberikan jaminan kepada perusahaan PMA untuk mendirikan usaha di negara lain dan mendapatkan perlakuan yang sama dengan perusahaan PMDN.

Dalam semangat itu pula berkembang apa yang dikenal dengan integrasi ekonomi yang pada dasarnya mengintegrasikan ekonomi dalam suatu kawasan atau regional (sehingga kemudian dikenal juga dengan regionalisme)' dengan jalan memperkecil atau menghapus hambatan dagang baik non tariff barrier maupun tariff barrier. Tingkatan atau intensitas integrasi ekoomi suatu kawasan bisa berbeda dari tingkat paling longgar ke tingkat yang paling ketat (terintegrasi penuh) yaitu berurutan (1) preferential tariff agreement; (2) partial common union; (3) free trade area; (4) Custom union; (5) Common Market; (6) Economic Union (Appleyard, 1998). Dalam alam yang semakin terintegrasi itu maka pada masa mendatang negara hampir, tanpa batas (borderless state). Pesaing industri dalam negeri bukanlah hanya industri setempat melainkan secara langsung adalah bisnis internasional. Bisnis yang tidak efisien mau tidak mau harus minggir dari persaingan internasional itu.

\section{Usaha Kecil dalam Globalisasi}

Pertanyaan penuh sangsi yang kemudian muncul adalah, bagaimana nasib ekonomi usaha kecil dan gurem yang - terserak? Masih relevankah koperasi yang selalu mengidentikkan diri sebagai wadah usaha kecil yang terserak? Haruskah kita mendukung koperasi ataukah sebaliknya kita mendukung usaha besar untuk bisa bersaing dengan perusahaan multinasional (multinational corporation)?

Koperasi pada dasarnya merupakan lembaga ekonomi yang muncui sebagai akibat dari adanya kebutuhan dari anggotanya untuk bersatu. Sebagai lembaga pemersatu ekonomi rakyat koperasi berperan untuk mempersatukan dan memperkuat posisi tawar menawar secara bersama (collective bargaining) terutama dalam menghadapi kekuatan dari luar sebagai "lawan"nya. Di dalamnya terkandung dua hal penting yaitu. Pertama, para anggota koperasi sadar bahwa kekuatan masing-masing amat lemah dan kecil untuk menghadapi keḱuatan lain. Namun, kedua, masing-masing anggota itu menyadari bahwa di dalam dirinya yang "lemah" itu sebenarnya terkandung potensi kekuatan:yang apabila dikembangkan akan menumbuhikán kemandirian (self relience). Kedua hal inilah yang pada akhirnya mendorong kelompok miskin dan lemah itu bersepakat untuk berkoperasi.

Dalam koperasi, kedua hal itu di kena! sebagai asas "individualitas dan solidaritas." Asas individualitas (sadar diri) dimaksudkan sebagai "sifat pada seseorang yang menandakan kehalusan budi beserta dengan keteguhan wataknya, yang memaksa orang lain untuk menghargaidan 
memandang akan dia". Individualitas berbeda dengan individualistik yang menuntut adanya kemerdekaan orang seorang untuk mencapai keperluan hidupnya. Solidaritas dimaksudkan sebagai upaya untuk memenuhi kebutuhan dengan cara saling tenggang antar sesama. Dengan demikian diharapkan kemandirian masyarakat itu akan bisa tercapai.

\section{Mengembalikan pasar dengan Collective Bargaining}

Dalam sejarah koperasi di Indonesia memang koperasi diwarnai oleh kecenderungan adanya dari pemerintah, menyebabkan koperasi kehilangan jati dirinya sebagai institusi ekonomi rakyat. Hal ini karena dalam proteksi terkandung upaya mobilisasi massa untuk pemilu sehingga lembaga koperasi dan semua lembaga petani dijadikan sebagai alat mobilisasi massa. Ide mengenai koperasi sebetulnya sejalan dengan ide persaingan bebas yang masih murni (belum terdistorsi). Koperasi hanyalah sekedar menyatukan kekuatan yang terserak untuk menghadapi kekuatan lain yang lebih besar, sehingga persaingan menjadi lebih adil, 'semua pelaku mempunyai posisi tawar yang sama. Sebagaimana diketahui perkembangan kapitalisme industrial dengan peran kuat oligopolis dan monopolis membuat pasar menjadi terdistorsi, ada kekuatan yang bisa menentukan harga (price setter) yang harus diikuti oleh usaha usaha gurem sebagai pengekor (price taker) seberapapun susahnya. Karena telah timbul kekuatan besar itulah koperasi sekedar ingin mengimbangi dengan melakukan pengumpulan kekuatan yang terserak agar mereka yang terserak itu bisa berdiri sama tinggi duduk sama rendah dengan usaha besar. Hanya itu!
Oleh karena itu pada masa globalisasi dan liberalisasi ide dasar koperasi justru menjadi semakin relevan. Dalam alam proteksi, usaha usaha gurem di dalam negeri harus banting tulang untuk menghadapi usaha besar di dalam negeri. Pada masa mendatang usaha besar di dalam negeri yang selama ini berhadapan dengan usaha gurem akan berhadapan dengan kapitalisme dunia atau multinational dan transnational corporation, dan sangat mungkin takluk. Bisa dibanyangkan bagaimana beratnya kehidupan usaha kecil dimasa datang. Berhadapan dengan usaha raksasa dalam negeri saja mereka tidak berdaya. Yang dihadapi oleh mereka bukan sekedar bersaing secara efisien di pasar dengan usaha besar. Lebih dari itu usaha besar dengan segala upayanya selalu melakukan "gerilya" dalam mempengaruhi kebijakan ekonomi yang dibuat oleh pemerintah. Dengan kekuatan, uangnya mereka membuat peristiwa ekonomi selalu penuh dengan misteri. Pembagian lisensi monopoli penuh dengan misteri. Pemenang tender suatu proyek tidak selalu berdasarkan efisiensi. Itulah yang selalu nampak dalam kehidupan bisnis. Lantas bagaimana dengan usaha gurem di era globalisasi? Bukankah usaha besar itu bukan lagi besar menurut ukuran dalam negeri melainkan pasti ukuran dunia? Kekuatan apa yang dipunyai untuk menatap kapitalisme dunia?

Kalau tanpa globalisasi saja koperasi diperiukan untuk meningkatkan bargaining power, maka pada masa globalisasi peningkatan collective bargaining lewat koperasi menjadi sebuah keniscayaan. Koperasi sama sekali bukan faktor pendistorsi pasar dengan berbagai proteksinya (bahkan koperasi sebenarnya "anti campur tangan pemerintah!") melainkan 
harus diartikan sebuah upaya untuk menghilangkan distorsi pasar sebagai akibat dari kecenderungan terjadinya monopolisasi, baik monopolisasi oleh perusahaan dalam negeri apalagi oleh kapitalisme dunia.

Dalam kerangka globalisasi maka pengembangan koperasi harus dikembalikan pada khittah semula: kembali ke jalur pasar dan sekaligus kembali kepada kekuatan ampuh dari usaha kecil: maju secara bersama sama menantang usaha usaha raksasa. Buktikan bahwa maju bersama akan sama kuat bargainingnya dengan usaha raksasa. Contoh mutakhir bagaimana kekuatan kecil yang terserak bisa menghadapi bahkan meruntuhkan usaha besar bahkan multinasional adalah gerakan damai sebagian masyarakat Timur Tengah pasca pendudukan Israel. Sejumlah besar perusahaan multinasional kalang kabut dan menutup usahanya di sejumlah negara Arab, sekaligus sebaliknya menggeliatkan usaha kaum pribumi. Bukan dengan tariff barrier apalagi non tariff barrier yang sudah diharamkan di zaman globalisasi dan liberalisasi ini, melainkan dengan menyatukan semangat mereka.
Tidak ada satupun pasal yang dilanggar, tetapi amat efektif hasilnya. Ini merupakan pelajaran yang harus ditangkap bahwa hanya kerjasama diantara kekuatan yang terserak yang mampu melawan dan melindungi diri dari persaingan dengan usaha asing.

Keandalan koperasi sebagai cara untuk meningkatkan collective bargaining sebenarnya telah ditunjukkan dinegara negara maju sebagaimana disajikan dalam tabel 1.Dari tabel nampak bahwa di negaranegara maju koperasi yang berintikan kepada collective bargaining mengambil peran yang sangat signifikan dalam pemasaran. Mereka menangani 25-50 persen dari pasokan dan pemasaran barang pertanian di AS dan Eropa. Misalnya industri susu di Denmark, padi padian di Canada, pemasaran beras di Jepang semua didominasi oleh koperasi. Koperasi juga sangat kuat perannya pada industri susu di Irlandia, Norway, Sweden, Findland yang menguasai lebih dari 78 persen pemasaran susu. Demikian juga dengan bank koperasi di Eropa dan Jepang mereka termasuk dalam jajaran institusi bisnis keuangan

Tabel 1. Pangsa Pasar Koperasi dalam Agribibisnis di Sejumlah Negara Maju (dalam persentase)

\begin{tabular}{|c|c|c|c|c|c|c|}
\hline Country & Susu & $\begin{array}{l}\text { Padi- } \\
\text { padian }\end{array}$ & $\begin{array}{l}\text { Buah } \\
\text { buahan }\end{array}$ & $\begin{array}{l}\text { Pemoton } \\
\text { gan }\end{array}$ & Anggur & $\begin{array}{l}\text { Pakan } \\
\text { ayam }\end{array}$ \\
\hline Belgia & 70 & - & 65 & 15 & & - \\
\hline Denmark & 87 & 15 & - & 90 & . & 55 \\
\hline Finlandia & 98 & 73 & - & 94 & & 60 \\
\hline Perancis & 44 & 52 & 28 & 37 & 68 . & \\
\hline Ireland & 100 & - & 34 & $20-35$ & - & 64 \\
\hline Netherlands & 87 & - & 80 & 25 & . & 17 \\
\hline Norwegia & 100 & . & 40 & 74 & - & 73 \\
\hline Swedia & 99 & 80 & $-\quad " \cdot$ & 80 & & 70 \\
\hline Amerika Serikat & 78 & 41 & 17 & - & $\cdot$ & 8 \\
\hline Jerman Barat & 79 & 55 & 46 & 30 & 35 & \\
\hline
\end{tabular}

Sumber: David Cobia, 1994 
terbesar di negaranya. Tetapi dominasi itu berlangsung secara alamiah dalam arti tidak mendapat proteksi dari pemerintah karena mereka ada dalam kelompok neutral policy yang memperlakukan koperasi sebagaimana mereka memperlakukan pada usaha lainnya. (Cobia, 1994)

Karena posisi pentingnya dalam pertanian, koperasi di negara-negara maju mempunyai peran yang penting dalam kebijakan pertanian. Koperasi bisa menegosiasikan dengan pemerintah dalam menerapkan suatu kebijaksanaan umum pemerintah termasuk di dalamnya dalam hal tarif dan proteksi. Di AS koperasi menjadi jauh lebih besar sebagai sebuah group dari pada koperasi di negeri manapun. Tetapi Zen-noh di Jepang tetap merupakan yang terkuat di dunia.

Gambaran dari apa yang terjadi di negara-negara maju seperti itu seharusnya menjadi pelajaran berharga bagi negara sedang berkembang. Dalam alam yang liberal mereka justeru mendorong, atau paling tidak individu petani atau industri terdorong untuk membentuk kerjasama di antara mereka dalam rangka meningkatkan bargaining position. Hal ini harus dilakukan mengingat ekonomi kontemporer tidak lagi perfect competition sebagaimana diasumsikan oleh kaum klasik melainkan diwarnai dengan adanya distorsi pasar berupa ologopoli bahkan monopoli. Tanpa menyatukan kekuatan yang terserak maka usaha kecil secara individual tidak akan bisa menghadapi usaha besar. Hanya dengan menyatukan diri maka mereka akan mampu menantang usaha besar.

\section{Usaha Mikro Pasca Amandemen dari demokrasi ke Plutokrasi}

Perbincangan tentang usaha kecil dalam masa krisis menarik untuk diamati.
Bukan saja bertambah dan bergesernya istilah yang dipakai. Semula digunakan dikotomi "usaha besar" versus "usaha kecil " (UK) kemudian menjadi "usaha besar" versus "usaha kecil dan menengah" (UKM) dan terakhir digunakan "besar" versus "usaha kecil, menengah dan mikro" (UMKM). Penggolongan ke dalam "UMKM" penuh dengan nuansa pergulatan kepentingan meraih kue pemotongan utang. Bagian ini mencoba menggambarkan masa depan usaha mikro setelah pikiran globalisasi mempengaruhi sejumlah pihak sehingga pada akhirnya pasal 33 UUD 1945 harus diamandemen agar sejalan dengan semangat globalisasi sebagai sebuah preskripsi.

Dalam kaitan pengucuran kredit kepada usaha kecil sebagai akibat dari krisis itulah maka kita melihat betapa sibuknya berbagai pihak mencari definisi tentang usaha kecil. Namun nuansa yang muncul adalah adanya upaya berbagai kelompok untuk dijadikan sebagai usaha kecil dalam rangka perebutan kue yang namanya kredit murah atau bahkan pemotongan utang (hair cut). Bagi BPPN misalnya kredit untuk usaha kecil dimaksudkan sebagai kredit yang maksimumnya adalah Rp. 10 milyar, Departemen Koperasi dan UKM mematok kredit untuk usaha kecil sebagai kredit sebesar Rp. 5 milyar, Bank Mandiri menggunakan omset sebesar Rp.360 milyar sebagai patokan. Definisi definisi itu tentu amat berbeda dengan yang digunakan oleh Badan Pusat Statistik yaitu omset sebesar Rp.1 milyar dan kredit maksimum Rp400 juta. Demikian juga yang digunakan dalam PP no 5/1995 dan UU No 9 1995. Definisi terakhir ini tentu lebih spesifik kepada usaha yang memang kecil.

Pemerintah dan berbagai pihak telah amat sibuk membuat definisi dan upaya penyelamatan usaha besar, menengah dan 
kecil. Definisi yang tidak sama tentang apa yang disebut dengan kecil atau mikro menyebabkan upaya yang tidak fokus dalam penanganannya. Adakah sebenarnya definisi yang baku tentang usaha kecil berikut implikasi kebijakannya? Penggolongan besar, sedang, kecil, dan mikro tergantung institusi yang mendefinisikan sesuai dengan kepentingannya. Namun penggolongan seperti apa yang dilakukan menurut pasal 33 berikut penjelasan dari "Penjelasan Pasal 33" maupun dari tokoh yang merumuskannya? Usaha mikro seperti apa yang secara konstitusional diamanatkan untuk mendapatkan perhatian? Bung Hatta yang merupakan konseptor dari Pasal 33 UUD 1945 memberikan ilustrasi usaha mikro sebagai berikut:

Perusahaan kecil sebagai tukang membetulkan sepatu yang rusak, dagang kecil seperti kelontong yang masuk kampung keluar kampung memikul barang dagangannya, warung atau toko yang dikemudikan sendiri dengan bantuan keluarga saja

Sedangkan usaha yang tidak mikro dirumuskan sebagai

"Segala usaha yang hanya dapat dikerjakan bersama sama oleh bantuan banyak orang"

Batasannya sederhana dan tegas. Atas batasan usaha mikro dan bukan mikro itu kemudian pemetaan dan perlakuan atas usaha mikro dan bukan mikro juga tegas diamanatkan. Pada dasarnya Pasal 33 menempatkan koperasi sebagai bangun usaha yang paling sesuai dengan semangat kebersamaan atau demokrasi ekonomi dan oleh karena itu harus menjalankan usahanya sebagai koperasi.

Dalam Pasal 33 tercantum dasar demokrasi ekonomi, produksi dikerjakan oleh semua, untuk semua di bawah pimpinan dan penilikan anggota-anggota masyarakat. Kemakmuran masyarakatlah yang diutamakan bukan kemakmuran orang seorang. Sebab itu, perekonomian disusun sebagai usaha bersama berdasarkan atas asas kekeluargaan bangun usaha yang sesuai dengan itu adalah koperasi. (Penjelasan ayat 1 Pasal 33 UUD 1945)

Untuk menjabarkannya Bung Hatta menjelaskan bentuk kongkretnya.

Pada umumnya segala usaha yang hanya dapat dikerjakan bersama sama oleh orang banyak mestilah memakai bangun koperasi. Jika tidak tentu lambat laun timbul semangat kapitalisme dengan akibat pemerasan dan penindasan orang banyak yang dikenal oleh satu golongan yang cerdik dan bermodal.

Dari kutipan ini bisa ditangkap adanya keharusan bagi usaha besar untuk berkoperasi karena usaha besar itu mempunyai kecenderungan dan potensi untuk serakah yang merusak tatanan ekonomi. Bagi kelompok ini berkoperasi adalah sebuah keharusan. Pada awalnya pemerintah harus mengarahkan mereka untuk berkoperasi agar pada akhirnya ada perubahan perilaku dari individualistik ke arah usaha yang peduli terhadap nasib sesama. Pengaturan secara persuasif akhirnya diharapkan usaha besar mempunyai moralitas untuk membantu sesama sehingga penindasan atas orang banyak tidak terjadi.

Sebaliknya usaha mikro tidaklah mempunyai kewajiban untuk berkoperasi, mengingat kondisinya yang serba mikro. Berbeda dari usaha besar, berkoperasi bagi usaha kecil lebih merupakan sebuah hak dan bukan sebuah kewajiban. Sekiranya dengan koperasi mereka menjadi lebih baik, 
adalah hak dari usaha mikro untuk berkoperasi (dan kewajiban dari pemerintah untuk mewujudkannya). Tetapi sekiranya perikatan dalam koperasi justeru membuat "ribet" maka bolehlah (atau biarkan) ia mencari jalur kesendiriannya. Dalam kaitan ini bisa dikutipkan ungkapan yang terkenal dari Hatta:

Tetapi tidak segala usaha harus dilakukan secara koperasi. Usaha usaha yang dapat dikerjakan oleh orang seorang dengan tiada menguasai hajat hidup orang banyak bolehlah dikerjakan oleh orang seorang itu, Kecuali, kalau kepentingannya sendiri menghendaki perikatan dalam suatu badan usaha dengan orang lain yang serupa perusahannya. Perusahaan kecil sebagai tukang membetulkan sepatu yang rusak, dagang kecil seperti kelontong yang masuk kampung keluar kampung memikul barang dagangannya, warung atau toko yang dikemudikan sendiri dengan bantuan keluarga saja, pada dasarnya boleh berdiri sebagai usaha sendiri. Paksaan berkoperasi kepada perusahaan perusahaan kecil yang tersebar letaknya tidak pada tempatnya, malahan melanggar dasar koperasi.

Bagi usaha mikro, perolehan penting dari berhimpun adalah menguatnya daya tawar (collective bargaining). Usaha mikro seperti petani, peternak, pedagang perajin secara individual tidak mempunyai.kekuatan yang cukup untuk menghadapi usaha besar. Mereka hanya akan mengikuti apa yang dilakukan oleh usaha besar. Namun ketika mereka berhimpun maka kekuatan baru akan menantang kekuatan besar yang telah ada.

Dengan memahami bahwa bagi usaha besar "berkoperasi adalah sebuah kewajiban" dan bagi usaha mikro "berkoperasi adalah sebuah hak" maka menjadi ironis fakta penyikapan pemerintah terhadap usaha besar dan mikro pada masa kini. Usaha besar seolah mempunyai hak untuk hidup sendiri dan.tidak didorong untuk merasa berkewajiban untuk berkoperasi. Sebaliknya yang sering terjadi adalah bahwa usaha mikro, "atas dasar konstitusi", wajib masuk koperasi tetapi tidak diikuti dengan pemenuhan hak mereka untuk mencapai kehidupan lebih baik lewat perhimpunan yang mereka masuki itu.

Payung konstitusi atas usaha mikro bagi usaha mikro di Indonesia amatlah kuat kalau kita mengamati betul Pasal 33 UUD 1945 berikut penjelasan tekstual dalam "Penjelasan " maupun penjelasan dari tokoh penting dibalik Pasal 33, Bung Hatta. Tetapi kini, payung itu telah hilang karena secara resmi diamandemen oleh MPR dalam Sidang Umum MPR pada tahun 2001. Ayat $1,2,3$, dalam Pasal 33 lama memang tetap utuh dan ditambah dengan dua ayat lagi. Namun tetap utuhnya 1,2,3, Pasal 33 UUD 1945 menjadi tidak berarti sama sekali karena penjelasan dari ayat itu (bersama sama dengan semua penjelasan UUD 1945) dihapuskan. Esensi ayat hịlang karena, berbeda dari pasal pasal lain ${ }_{i j}$ penjelasan "ayat ekonomi" itu selain menjelaskan sekaligus mengandung ruhnya yang spesifik. Penghapusan penjelasan ini berarti hilangnya pengertian demokrasi ekonomi dan juga hilangnya kata koperasi sebagai bangun perusahaan yang sesuai dengan demokrasi ekonomi. Kalau penjelasan secara resmi atas pasal 33 saja telah dihilangkan, tentu berbagai penjelasan berupa pembatasan mengenai usaha besar dan mikro oleh individu (Bung Hatta) apalah lagi artinya. Dengan demikian perlakuan seperti apa yang harus diambil atas usaha mikro dan besar tidak lagi dalam kerangka permanen melainkan situasional tergantung pertimbangan ekonomi politik sesaat. 
Keputusan tentang pemihakan dan pembiayaan usaha mikro tidaklah terkait sama sekali dengan amanat ideologis konstitusi melainkan amat tergantung pada interaksi diantara para pelaku ekonomi politik.

\section{Globalisasi dan Usaha Kecil di Masa Mendatang}

Perekonomian yang mewajibkan usaha besar untuk beroperasi dalam koridor kebersamaan (koperasi) dan yang memberi hak kepada usaha mikro untuk berkoperasi (bukan kewajiban, dikejar kejar) adalah impian yang diperintahkan oleh konstitusi. Bahwa faktanya hal itu belum terealisasi, merupakan politik ekonomi jangka pendek yang mungkin bisa dipahami. Tetapi setelah amandemen UUD 1945 tahun 2001, impian yang harus diwujudkan itupun telah terhapus. Bangsa ini tidak lagi (secara konstitusional) bermimpi tentang pemihakan yang kebersamaan dan pengembangan usaha kecil. Seperti diketahui setelah amandemen Pasal 33 UUD 1945 tidak lagi memunculkan penjelasan yang memuat tentang pengembangan koperasi, dan otomatis penjelasan Bung Hatta tentang pemihakan atas usaha kecil dan bahaya kapitalisme bila usaha besar dibiarkan dikuasai orang seorang menjadi tidak relevan lagi. Pengembangan usaha kecil tak lagi mempunyai koridor konstitusi. Yang ada adalah proses ekonomi politik. Keputusan apakah harus pro terhadap usaha kecil atau besar semata mata hasil dari proses ekonomi politik diantara elit kekuasaan dan para pihak yang berkepentingan (interest group). Keputusan di bidang ekonomi telah bergeser dari demokrasi ke plutokrasi, yaitu keputusan yang dilakukan oleh segelintir orang yang mempunyai uang untuk mempengaruhi suatu keputusan.
Amandemen Pasal 33 adalah persoalan yang mendasar berkaitan dengan pemihakan terhadap usaha mikro. Hilang sudah "hak konstitusional" bagi pemihakan atas usaha mikro. Namun untungnya, sosialisasi amandemen pasal ini tidak cukup gencar. Berbeda dengan sosialisasi dan penerapan amandemen bidang politik amandemen Pasal 33 tidak mempunyai gaung. Tidak ada pro dan kontra yang meluas. Tidak ada upaya aktif untuk menyosialisasikan, tetapi juga tidak ada greget untuk menolaknya. Mengapa tidak ada penolakan yang "militan" dari gerakan koperasi dan usaha mikro yang masa depan kepentingannya terpangkas? Telah kalahkah mereka? Apakah mereka telah menerima argumen dan dengan sadar menerima? Yang terjadi sangat mungkin karena para anggota maupun institusi MPR sebenarnya tidak serius alias "mangro tingal" dan "malu malu" untuk tidak mengamandemen Pasal 33 ditengah arus deras reformasi bersemangatkan amandemen.

Dengan demikian kiranya bisa dipahami mengapa tingkat dukungan maupun tolakan atas amandemen Pasal 33 teramat minim. Para penggerak dan aktifis koperasi nampaknya tetap saja bekerja "sebagaimana biasa", tidak tahu bahwa sebenarnya landasan konstitusi bagi koperasi telah tiada. Ketidaktahuan itu barangkali bisa dianggap sebagai berkah tersembunyi yang perlu dibiarkan atau dilestarikan untuk mempertahankan moral. Tetapi pada tahap berikut kiranya "ketidaktahuan" itu harus diubah menjadi "ketahuan" sehingga kita bekerja "sebagaimana biasa" karena menganggap amandemen sebagai sebuah angin lalu. Tahu ada perubahan tetapi tidak menganggap ada. Mengingat strategisnya pemihakan atas usaha mikro dalam Pasal 
33, kiranya kita bisa mendukung gagasan biarkan anjing menggonggong kafilah tetap berlalu sebagaimana biasa. Dengan mengakui amandemen sebagai kenyataań, tetaplah mengutip Pasal 33 yang lama. Kalau berbicara pengembangan usaha kecil, bicaralah dalam kerangka. Biarkan publik tidak tahu bahwa konstitusi telah berubah. Sebuah potensi yang pada suatu saat akan berubah sebagai-bentuk penolakan ketika amandemen Pasal 33 akan diimplementasikan.

\section{Daftar Pustaka}

Arief, Sritua, Pembangunanisme Ekonomi Indonesia, Penerbit Zaman, Jakarta, 1998

Arief, Sritua, "Uang Luar Negeri dan PMA: Mitos dan Fakta", dalam Jurnal Wacana, 2001
Chossudovsky, Michael, The Globalization of Poverty, Impacts of IMF and World Bank Reforms, Thirld World Network, Penang, 1997

Hudiyanto, Koperasi, Sistem, Ideologi dan Pengelolaan, Uil Press, 2002

Mubyarto, Hudiyanto dan Agnes VM Mawarni, IImu Koperasi, akan terbit.

Petras, James $P$ \& Hensy Veltmeyer, Globalisation Unmusked, Imperialism in the 21th Century.

Stiglitz, Joseph, Globalisation and Its Discontents, New York, WW Norton, 2001

Todaro, Michael P, Economic Development in The Thirld World, Longman, 1998 